\title{
The Portuguese Serrana goat breed: a review
}

\author{
Laura Sacarrão-Birrento $^{1} \cdot$ André M. de Almeida $^{1}$
}

Received: 6 November 2020 / Accepted: 22 December 2020 / Published online: 12 January 2021

(C) The Author(s), under exclusive licence to Springer Nature B.V. part of Springer Nature 2021

\begin{abstract}
Goats were among the first animals to be domesticated over 10,000 years ago and are part of human societies since the beginning of agriculture. Goats play a major role both in commercial farming systems and in subsistence agriculture systems, particularly in tropical, subtropical and Mediterranean regions where they are crucial for the supply of meat, milk, fibre and dung. This review concerns the Serrana breed, the most important and numerous indigenous goat breed from Portugal that was furthermore exported to other regions of the world, notably South America during the Portuguese colonization. Herein, we describe the origin and history of the breed as well as the productive performance and most common production systems. Finally, we address the local and traditional PDO (protected denomination of origin) and PGI (protected geographical indication) that are produced from these animals.
\end{abstract}

Keywords Longhaired goat · Dairy goat · Goat ecotypes · PDO and PGI goat cheeses and kid meat

\section{Introduction}

Goats are associated with humans since the beginning of agriculture and animal domestication over 10,000 years ago. Presently and worldwide, goats play a very important role around the world both in commercial and in subsistence agriculture systems. Indeed, goats play a major socioeconomic role in many countries (Solaiman 2010) worldwide but with a particular relevance in the Tropics, Subtropics and the Mediterranean regions. In Portugal, goat production is extremely important, not only for the produced meat and milk, but also because they provide an income in impoverished and highly depopulated regions in mountainous regions of the interior and where alternative economic activities are scarce (Silva et al. 2007). This situation is analogous to those in other Mediterranean countries. In such regions, they furthermore play a major role in controlling biomass production and consequently in the prevention of bushfires.

Autochthonous or indigenous goat breeds represent a very valuable genetic heritage and have an extraordinary potential for both income generation and the maintenance of local

André M. de Almeida

aalmeida@isa.ulisboa.pt

1 LEAF, Instituto Superior de Agronomia, Universidade de Lisboa, Tapada da Ajuda, 1349-017 Lisbon, Portugal traditions in the regions where they are farmed. They therefore have an intrinsic value related to the local heritage and gastronomy, bringing additional benefits to local populations. Autochthonous goat breeds are therefore part of the country's historical and cultural heritage, originating traditional quality products (Pena 2018), some of them part of the EU certification schemes such as PDO (protected denomination of origin) and PGI (protected geographical indication).

These breeds are the result of domestic animal selection highlighting adaptation to local environments and production conditions. Indigenous breeds therefore have a high degree of adaptation and uniformity and are fully adapted to local production conditions, which are particularly harsh in most cases. This is in clear contrast with exotic breeds that, albeit with higher production levels per animal, lack such adaptation and production ability in difficult conditions (Mantas 2009). In Portugal, indigenous goat breeds are farmed chiefly in inland regions in balanced, ecological and sustainable extensive systems, in many cases unchanged for several centuries. Being mostly extensive systems, it is possible to use resources that would be wasted and at the same time produce highquality products of relevant economic value. Thus, the profitability of the farms is increased and the environment and cultural heritage are preserved. Autochthonous breeds show an enormous level of adaptability and resistance and represent an important genetic pool that can be of use as a response to several unforeseen factors such as climate change and disease 
outbreaks, furthermore fulfilling the nutrition requirements of an exponentially growing population, particularly those of proteinaceous foods (Dantas and Espadinha 2020).

Portugal, with 10 million inhabitants, is one of the richest countries in terms of domestic animal genetic diversity. The country has six goat autochthonous breeds officially recognized: Bravia, Serrana, Preta de Montesinho, Charnequeira, Serpentina and Algarvia. Such breeds represent only $12.5 \%$ of the total of the national goat inventory, whereas exotic breeds represent only $5 \%$ of such inventory. The remaining percentage is a result of crosses between several breeds (Carolino et al. 2017), a very important problem, particularly in goats. The most representative breed is the Serrana goat with around 14,500 females registered in the herd book, followed by the Bravia breed with 11,400 females (SPREGA 2020). Portuguese breeds have very diverse genetic differences that are not influenced by geographical distribution. For example, Serpentina and Charnequeira are geographically close, albeit being the most divergent breeds. On the contrary, Bravia and Algarvia are geographically the most distant breeds, but with the highest breed similarity (Pereira et al. 2005). Like many other Portuguese domestic animal breeds, these animals were transported to former Portuguese colonies in the tropics and the subtropics, particularly Brazil, where they were used in the formation of local breeds and have shown to be particularly adaptable to local conditions.

The objective of this review is to describe and globally characterize the Portuguese Serrana goat breed. We will start to describe the origin and history of the breed . Subsequently, we describe the breed standards as defined by the Portuguese Serrana Breeders Association that manages the herd book. In the third section, we will describe the breed production performances concerning milk and meat. In the fourth section, we will describe the uses of the breed in Portugal. In the fifth section, we will address the use of Serrana animals in the establishment of goat breeds elsewhere. Finally, we will end this review with major conclusions and some future perspectives for the Serrana breed in the present context.

\section{Origin and history of the Serrana breed}

Goats were the first animal to be domesticated over 10,000 years ago. Some authors describe that domesticated goats were adapted from wild bezoar ibex (Capra aegagrus) since Neolithic farmers started keeping them to use their milk and meat (Hirst 2019). On the contrary, other authors consider the existence of three groups involved in the origin: Capra aegagrus that belongs to the European group (Ovis capra europaea), Capra falconeri and Capra prisca belonging to the Asian group (Ovis capra asiatica) and Capra nubiana or sinaiatica belonging to the African group (Almendra 1996; Ministério das Obras Públicas, Comércio e Industrias 1873;
Kukovics 2018). Solaiman (2010) considered the existence of five wild ancestors: Capra hircus (the true goat including the bezoar), Capra ibex (the ibexes), Capra caucasica (the Caucasian tur), Capra pyrenaica (Spanish ibex) and Capra falconeri (the markhor).

Despite the fact that their origin is not fully clear, Portuguese goat breeds have been indicated in previous studies to have descended from three groups of goats of the Quaternary. In the Iberian Peninsula, with animal evolution and because of migrations in mountain ranges, the Pyrenees goat (Capra pyrenaica) replaced the original wild species. Capra pyrenaica was therefore the direct ancestor of Portuguese and Spanish breeds (Almendra 1996). According to Bruno-de-Sousa et al. (2011), the Bravia and the Algarvia breeds descend from independent ancestral populations whereas other breeds descend from various ancestral populations present in the Iberian Peninsula for a long time. Autochthonous breeds closely located show a weak differentiation although present high levels of genetic diversity. Some specific Portuguese goat breeds originated from a Brazilian breed (Crespa) as a result of the introduction of animals during the colonial period. Lopes et al. (2016) for instance clearly established the Algarvia and Serrana breeds as being the sources of the Crespa breed.

The origin of the Serrana breed is not fully known and it is difficult to determine (DGAV 2018). Archaeology studies found ancestral fossils that date to the Quaternary period of the Cenozoic era, i.e. 3 million years ago, suggesting that the origin was the previously mentioned wild species. According to Almendra (1996), there was another wild species in the Gerês mountain region (Northern Portugal) that was hunted to extinction in the last decade of the nineteenth century. It was called Capra lusitanica or wild Gerês goat. It is believed that it was one of the closest wild relatives of the Portuguese breeds.

In 1873, in the general livestock census of Portugal, there was already reference to two different goat groups spread across different regions. They were classified as either longhaired or shorthaired goats. There was also a clear size distinction according to the region of the country. The smallest animals were found in the Barroso mountain range in Northern Portugal, whereas the heaviest animals were found in the vicinity of Lisbon and in the Serra da Estrela mountain range (Central Portugal). Medium-sized animals were located mostly in the Alentejo and Ribatejo provinces in Southern Portugal (Ministério das Obras Públicas, Comércio e Industrias 1873).

Subsequently, in 1926, Portuguese goats were classified as either Serra da Estrela with Jarmelo and Saloia ecotypes or Charnequeira (also known as Serrana) with Barrosã, Ribatejana and Alentejana ecotypes. The first had long hair, a large frame, a large udder and high production levels. The second group had short hair and were smaller (Correia 2004).

In the 1950s, two groups were further separated: the Serrana breed and the Charnequeira breed with different 
morpho-functional characteristics (Almendra 1996). In 1990, the National Serrana Breeders Association (ANCRAS) was founded, and in 1992, it became the official managing entity of the breed herd book (Castro 2016).

The only certainty is that Serrana goats originate from the Serra da Estrela mountain range in Central Portugal. From there, they spread throughout the country to the Trás-osMontes, Ribatejo and Estremadura regions (Fig. 1). Over the years, the number of goats of this breed has decreased and nowadays we cannot see this breed in the northeast and central regions of the country, whereas 40 years ago it was quite common in coastal areas. The breed evolved into four ecotypes depending on the climate and region: (a) Transmontano from the north-western interior of Portugal (Vila Real and Bragança districts in the Trás-os-Montes region); (b) Jarmelista from the central mountainous regions (Guarda, district in the Beira region); (c) Ribatejano from the Santarém, Leiria and Lisboa districts in the Ribatejo and Extremadura regions. Finally, a fourth and almost extinct Serra ecotype can be found in the Serra da Estrela mountain range, also in the Guarda, Castelo Branco and Viseu districts in the Beira region (Pereira 2005).

In 1996, the Official Journal of the European Communities registered five traditional products made with products obtained from the Serrana goat breed, two as protected denominations of origin (PDO): Queijo de Cabra Transmontano (Transmontano goat cheese) and Cabrito Transmontano (Transmontano kid); three as protected geographical indications (PGI): Cabrito do Barroso (Barroso kid), Cabrito das Altas Terras do Minho (Minho Highlands kid) and Cabrito da Beira (Beira kid) (Pereira 2005). Presently, the Serrana breed is the most important autochthonous Portuguese breed with 14,528 females and 662 males registered (SPREGA 2020), being the only breed currently not in danger of extinction.

\section{Serrana breed standards}

The breed standards are described in the webpage of ANCRAS and are shown in Fig. 2.
Fig. 1 Origin of the Serrana breed in the Serra da Estrela mountain range in Central Portugal and subsequent migration to other regions of the country where the different ecotypes were established

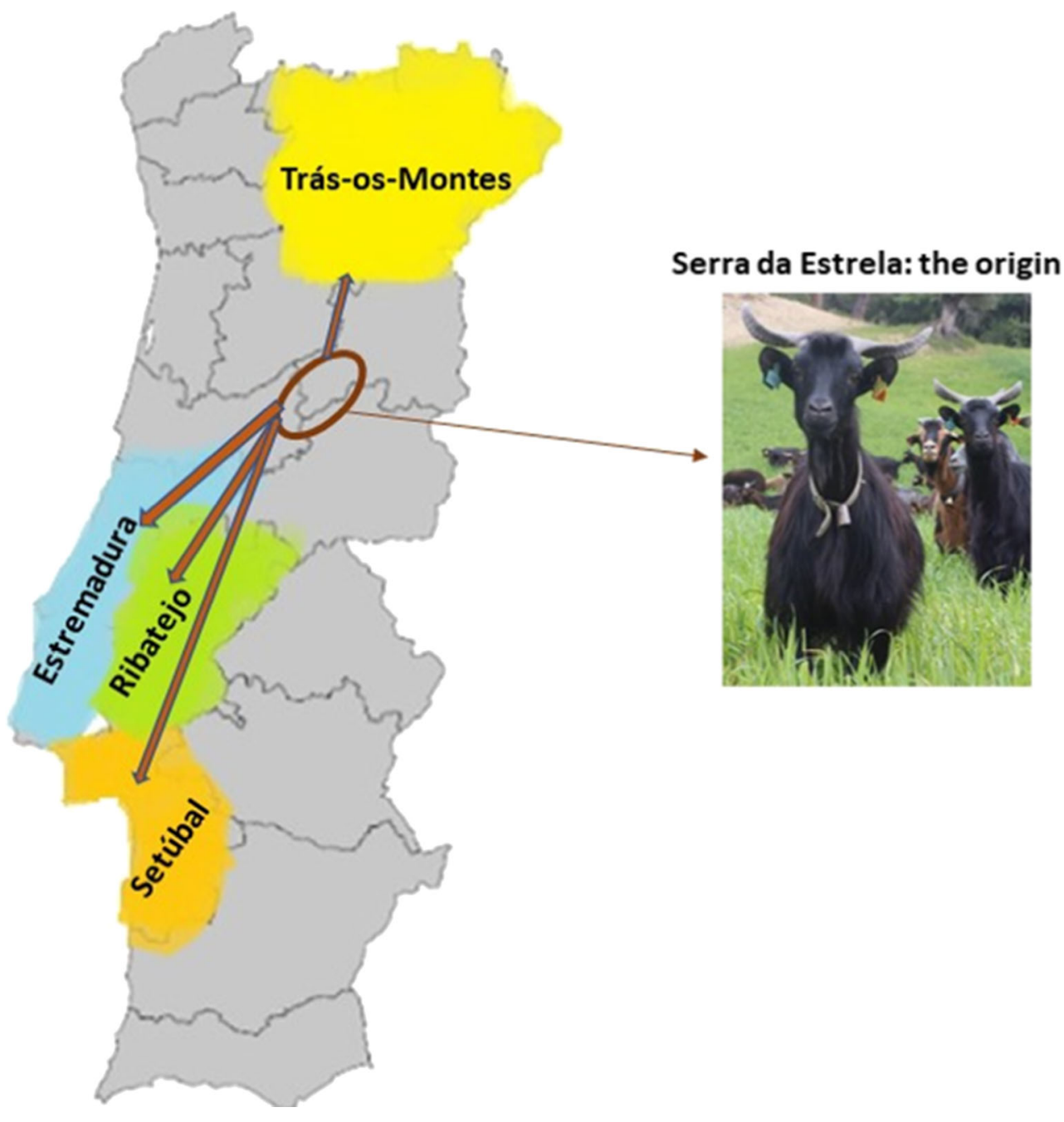




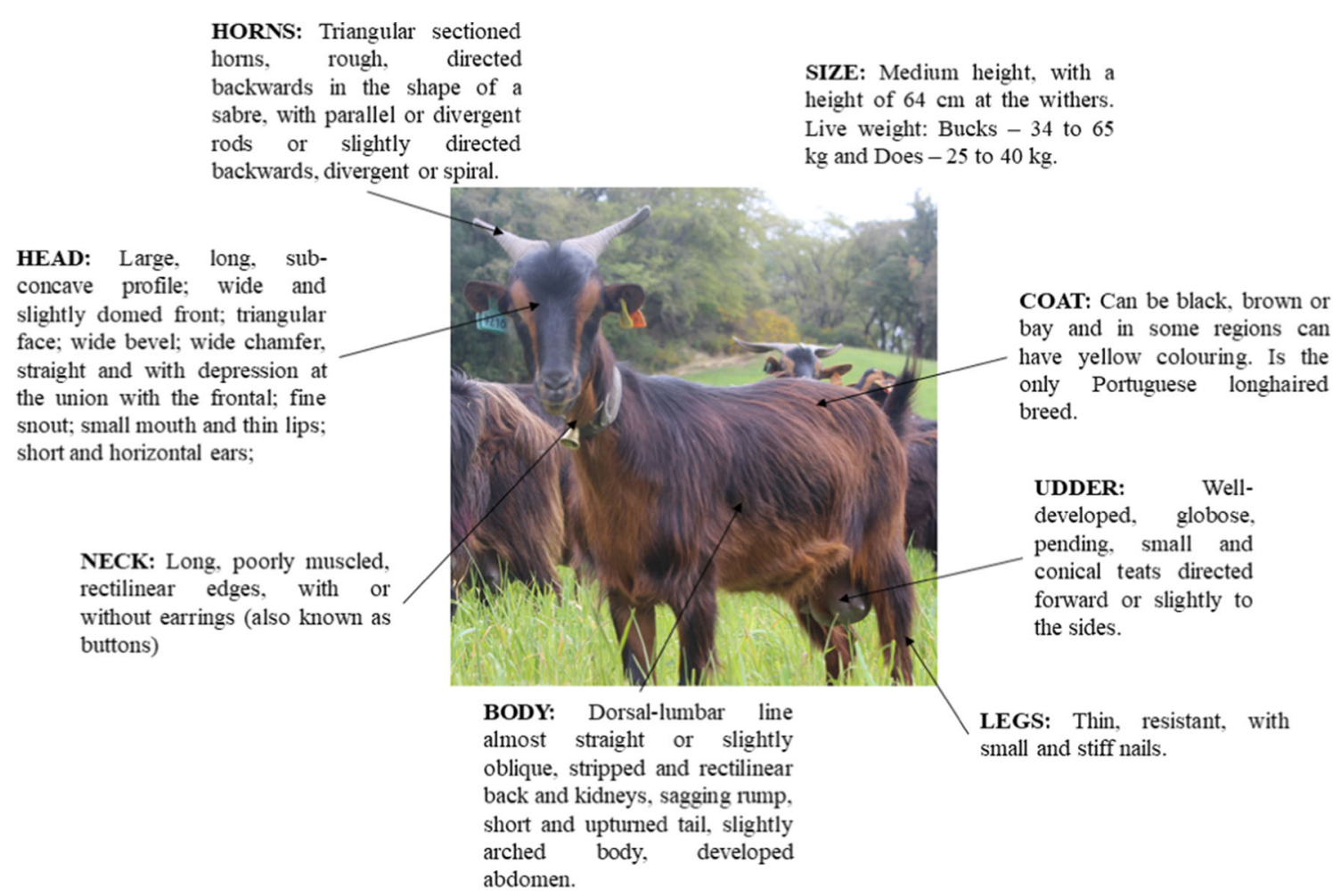

Fig. 2 Standards of the Serrana breed. Adapted from ANCRAS (2020)

According to Margatho et al. (2020), Serrana goats can have a pear-shaped or pendular cylindrical udder, but the most prominent shape is globular as described by ANCRAS (2020). The udder perimeter is $31.3 \pm 9.1 \mathrm{~cm}$, the udder cleft $21.6 \pm 8.0 \mathrm{~cm}$ and the udder depth $6.4 \pm 4.0 \mathrm{~cm}$. The udder shape is very important in milk production as it can be related to the occurrence of mammary infections or mastitis. Goats with a pendular cylindrical udder present a higher somatic cell count, and goats with globular and pear-shaped udders are more likely to have infections.

The standards are the same for the four ecotypes, and the only difference is the coat colour: ecotypes of Serra and Ribatejano have a black coat with black legs and the Ribatejano may also have a dark brown colour. The Jarmelista ecotype is brown with brown legs or bay with brown legs. The Jarmelista ecotype features additionally two streaks on the face, lighter brown in colour, and Ribatejano can have these streaks as well (Pereira 2015). Finally, the Transmontano ecotype has a very distinctive silver coat, very different from all the others. In Fig. 3, we present the difference of colours in the Serrana breed.

\section{Serrana breed production performance}

Serrana goat is farmed mostly as a dual-purpose breed used in meat and milk production (Pires et al. 2015). However, in some regions, it is used primarily for dairy production
(Pereira 2005). Goats from temperate regions reproduce preferentially on decreasing photoperiod months (late summerautumn). Generally, goats from South Europe are less seasonal and some females can show oestrus and ovulation yearround (Mateus et al. 2015). In the study done by Simões and Bauer (2017) using data collected between 1987 and 2015 from records of the herd book and in order to describe the reproductive profile and milk production of the Serrana breed, the authors concluded that natural mating in Serrana goats has two clear kidding peaks as shown in Fig. 4. One of the peaks occurs in January and the other in October so it means that natural breeding occurs respectively in August and May. From January until June/July, the kidding percentage decreases coinciding with the natural breeding season. The increasing percentage until October confirms the sexual activity in the non-reproductive season from this breed.

The age to puberty is influenced by the birth season. Kids born in winter reach puberty earlier at 7 or 8 months than kids born in summer that reach puberty around 11 months (Correia et al. 2001). According to ANCRAS, the age at puberty is between 8 and 12 months, a 4-month interval that can be explained by the birth season. Multiparous goats usually have a higher percentage of polyovulatory oestrus than nulliparous ones (Simões et al. 2008). Ovulation can occur in just one ovary or in both, and Serrana goats present a high percentage in both ovaries. The mean for the interovulatory interval can be $21.2 \pm 0.8$ days (Simões et al. 2006) or $21.1 \pm 0.3$ days (Simões and Mascarenhas 2007), and in multiparous goats 
Fig. 3 Serrana goats of the four different ecotypes. a Goats of the Ribatejano ecotype (brown animals) and the Transmontano ecotype (silver coat animal at the centre). b Jarmelista ecotype kid. c Serra ecotype with the distinctive black coat. $\mathbf{d}$ Ribatejano ecotype goats with dark brown coat. All photos by the authors
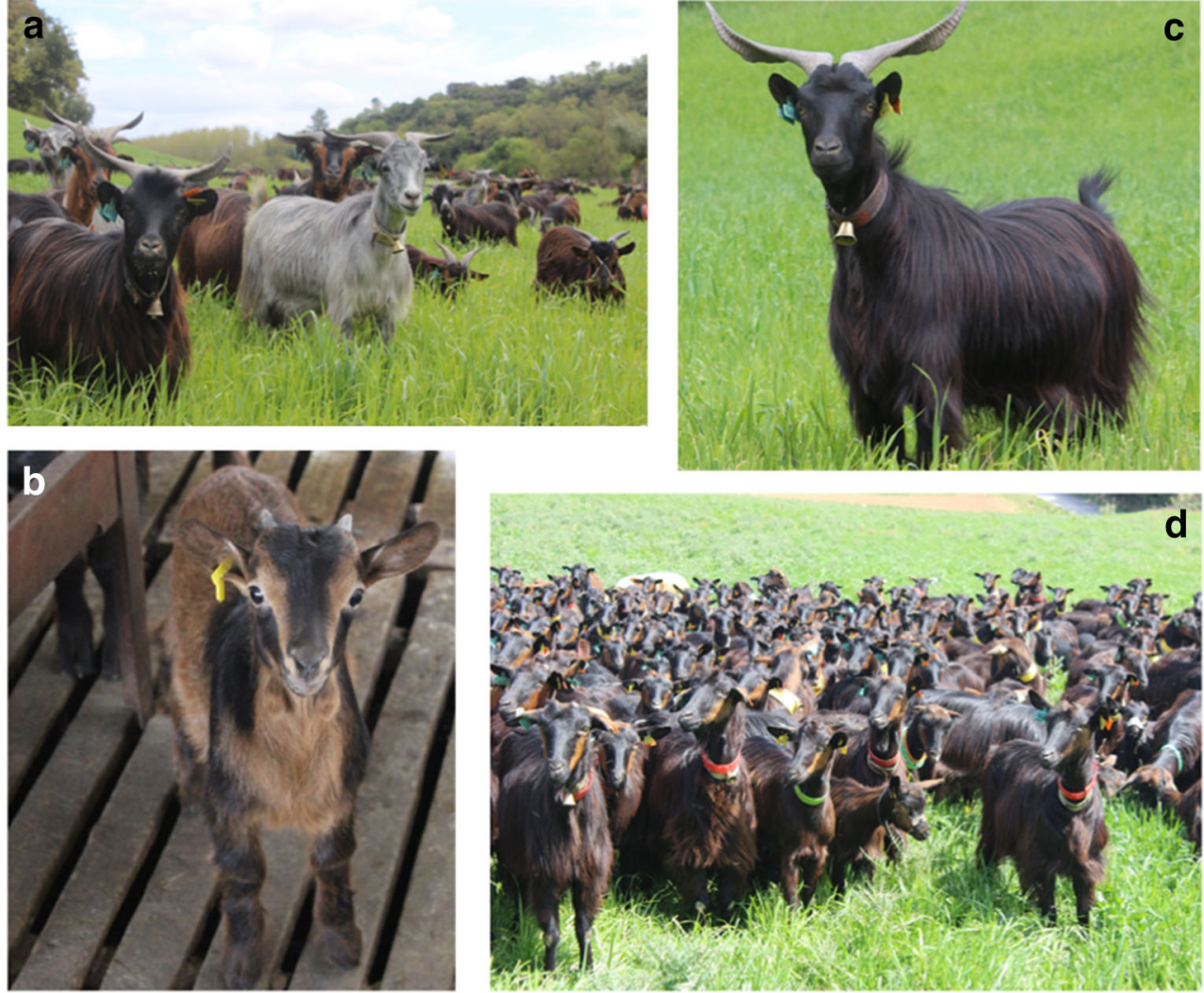

this interval is larger (Simões et al. 2006). In goats where ovulation occurs in both ovaries, the first preovulatory follicle emerges earlier than the second, both with the same diameter, suggesting that an ovarian endogenous factor can exert an influence (Simões and Mascarenhas 2007). Serrana goats can have three to five waves per oestrous cycle but in most cases have four and the first one is longer than the others (Simões et al. 2006).

The duration of gestation in goats is usually 149 days but can vary between 144 and 150.8 days. The gestation period can be influenced by season of the year, parity, age of the dam, sex and number of kids at birth (Solaiman 2010). Ribatejano and Transmontano are furthermore the most prolific ecotypes with 1.43 to 1.63 kids per kidding (ANCRAS 2020; Margatho et al. 2019). Breed fertility is high varying between 90 and $95 \%$ and prolificity rates are between 170 and 180\% (ANCRAS 2020), presenting frequently twin births (Pereira 2015).

Regarding milk production, Serrana breed ecotypes show considerable differences. Data from records of the herd book between 1987 and 2015 were described by Simões and Bauer (2017). The results showed that the most productive ecotype is the Ribatejano with $220.7 \pm 0.5 \mathrm{~L}$ produced per 150 days of normalized lactation. The mean milk production for the Transmontano ecotype is $96.1 \mathrm{~L}$, being heavily influenced by the number of lactations. The production per lactation tends to increase until the fourth $(101.0 \pm 0.3 \mathrm{~L})$ lactation, is typically maintained during the fifth and sixth lactations and starts to decrease after that. Margatho et al. (2019) described the same for this ecotype; the first lactation is the lowest ( 90.1 $\pm 32.2 \mathrm{~L})$, reaching the maximum at the third $(100.2 \pm 40.7 \mathrm{~L})$, and starts to decrease before, remaining higher than the first until the tenth lactation. The Jarmelista ecotype presents a 150 -day normalized milk production of $146.7 \pm 0.4 \mathrm{~L}$. These values are lower than the values from Serrana breed standard (Table 1) probably because they used a longer range of years and ANCRAS used values obtained during the 2012 to 2015 seasons. Indeed and according to ANCRAS (2020), the average daily milk productions are $0.59 \mathrm{~L}, 1.45 \mathrm{~L}, 1.14 \mathrm{~L}$ and $1.02 \mathrm{~L}$ for the Transmontano, Ribatejano, Jarmelista and Serra ecotypes, respectively. Although Ribatejano is the most productive, the Transmontano ecotype can furthermore produce milk longer than the other ecotypes. Milk from the Serrana breed is used in cheese production, so milk solid content is of the utmost importance. With data collected from the bulk tank of 42 Serrana goat dairy herds, it was possible to determine the mean percentage of milk protein, fat, lactose and solids-not-fat: $3.63 \pm 0.24,5.22 \pm 0.70,4.72 \pm 0.25$ and $8.92 \pm 0.44$, respectively (Margatho et al. 2018). Milk composition is influenced by several factors: season, amount of milk produced and stage of lactation (Margatho et al. 2018). Milk yield and protein percentage may be influenced by exons of the gGH (growth hormone) gene. Indeed, and according to 
Fig. 4 Monthly distribution (in percentage) of parturitions by natural mating of Serrana goats. Adapted from Simões and Bauer (2017)

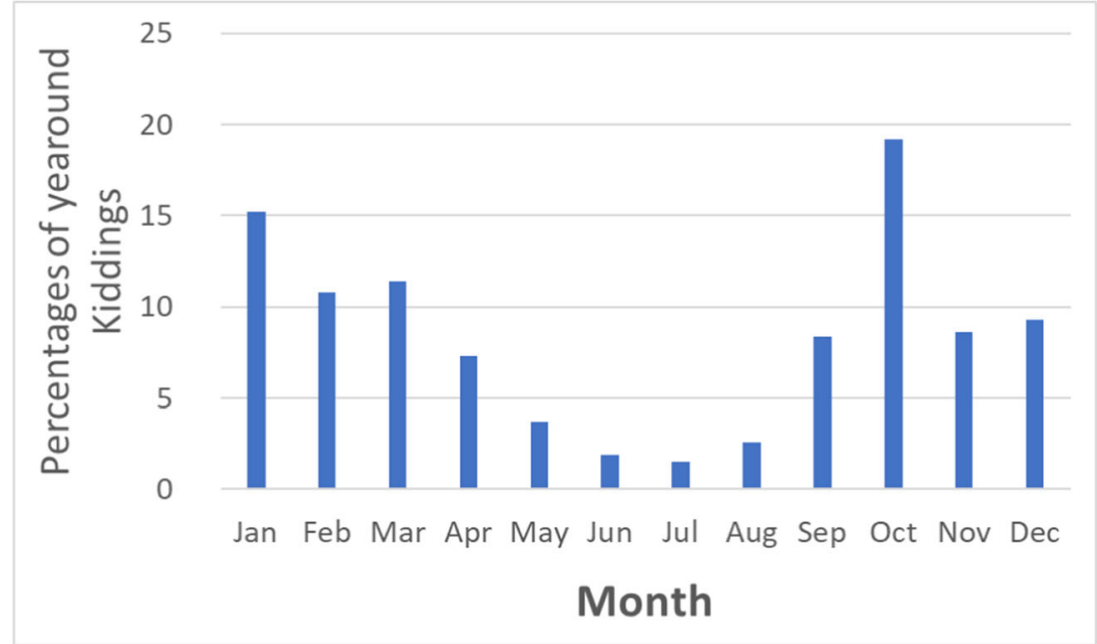

Marques et al. (2003), in Serrana goats, exons 2 and 4 positively influence milk yield and exons 1 and 2 the protein percentage.

Comparing the Serrana breed dairy production standards to those of the most productive breeds that are used in many countries around the world for milk production (Saanen and Alpine), the production traits for the Serrana goat are relatively low as observed in Table 1. Saanen and Alpine goats produce milk twice as much as that produced by Portuguese goat breeds and their lactation lasts more than 300 days. Indeed, the average daily productions of Saanen and Alpine breeds are 3.1 L and 3.04 L, respectively; however, the fat and protein contents are lower than those in the Serrana breed.

Aiming to evaluate the effects of non-genetic factors on weights and on average daily gain of Transmontano kids, Jiménez-Badillo et al. (2009) analysed data from 3 years' performance records from 8930 animals from the ANCRAS herd book. The birth weight average was $2.3 \pm 0.41 \mathrm{~kg}$, the adjusted live weight at 30 days was $5.8 \pm 0.02 \mathrm{~kg}$, the weaning weight was $8.2 \pm 0.07 \mathrm{~kg}$ and the male kids were as expected heavier than females. Another effect was the dam's age as it was observed that kids from does kidding in the first year were lighter at birth and at weaning time than the kids of goats kidding on their 2 nd-5th parturition.
Climate conditions also had an influence on these parameters as they have strong implications for pasture production and the nutritive value of grass and forage, hence affecting nutrition. As winter and summer have the worst conditions for goat production, kids born in autumn were the heaviest and a higher weaning weight was obtained in kids born in spring. These values are within the range described by ANCRAS in the breed standards (birth weight between 2.2 and $3 \mathrm{~kg}$, live weight at 30-40 days between 6 and $8 \mathrm{~kg}$ ).

The carcass from Serrana kids shows a lower proportion of subcutaneous and intermuscular fat deposits and higher proportion of muscle. By the preferences of Mediterranean consumers, these characteristics increase the potential of the breed because it makes it a lean meat source (Teixeira et al. 1995). According to Quaresma et al. (2016), the meat presents a lower total lipid content and a higher content of total cholesterol than that of kids from non-certified breeds and twice the total PUFA content and three times the content of n-3 PUFA. Teixeira et al. (2015) conducted a study using 400 Serrana goats aged between 5 and 9 years old and with live weights between 35 and $40 \mathrm{~kg}$. The authors ascertained the chemical composition of fresh meat, and observed a mean of $21.17 \%$ for protein content, $76.25 \%$ for moisture content, $2.44 \%$ for ash content, $0.87 \%$ of connective tissue content and $2.37 \%$ of
Table 1 Milk production standards from the Serrana breed by ecotype and from the Saanen and Alpine breeds

\begin{tabular}{lllllll}
\hline & Transmontano & Ribatejano & Jarmelista & Serra & Saanen & Alpine \\
\hline Total milk production (L) & $105.3^{\mathrm{a}}$ & $247.7^{\mathrm{a}}$ & $178.4^{\mathrm{a}}$ & $156.2^{\mathrm{a}}$ & $994.0^{\mathrm{c}}$ & $933.0^{\mathrm{c}}$ \\
Daily average production (L) & $0.59^{\mathrm{a}}$ & $1.45^{\mathrm{a}}$ & $1.14^{\mathrm{a}}$ & $1.02^{\mathrm{a}}$ & $3.1^{\mathrm{c}}$ & $3.04^{\mathrm{c}}$ \\
Lactation duration (days) & $177.2^{\mathrm{a}}$ & $170.2^{\mathrm{a}}$ & $157.8^{\mathrm{a}}$ & $154.6^{\mathrm{a}}$ & $321.0^{\mathrm{c}}$ & $307.0^{\mathrm{c}}$ \\
Milk fat (g/100 g) & $5.22^{\mathrm{b}}$ & & & & $3.66^{\mathrm{c}}$ & $3.56^{\mathrm{c}}$ \\
Milk protein (g/100 g) & $3.63^{\mathrm{b}}$ & & & & $3.24^{\mathrm{c}}$ & $3.35^{\mathrm{c}}$ \\
Prolificacy (kid/parturition) & $1.45^{\mathrm{a}}$ & $1.63^{\mathrm{a}}$ & $1.37^{\mathrm{a}}$ & $1.38^{\mathrm{a}}$ & - & - \\
\hline
\end{tabular}

${ }^{\text {a }}$ Source: ANCRAS (2020)

${ }^{\mathrm{b}}$ Source: Margatho et al. (2018)

${ }^{\mathrm{c}}$ Source: France Génétique Elevage (2015) 
Fig. 5 Steps for traditional cheese making. a The milk is heated and the curd is formed. $\mathbf{b}$ The curd is pressed manually. $\mathbf{c}$ The curd is placed in moulds. d Maturation rooms with fresh and cured cheeses. All photos by the author
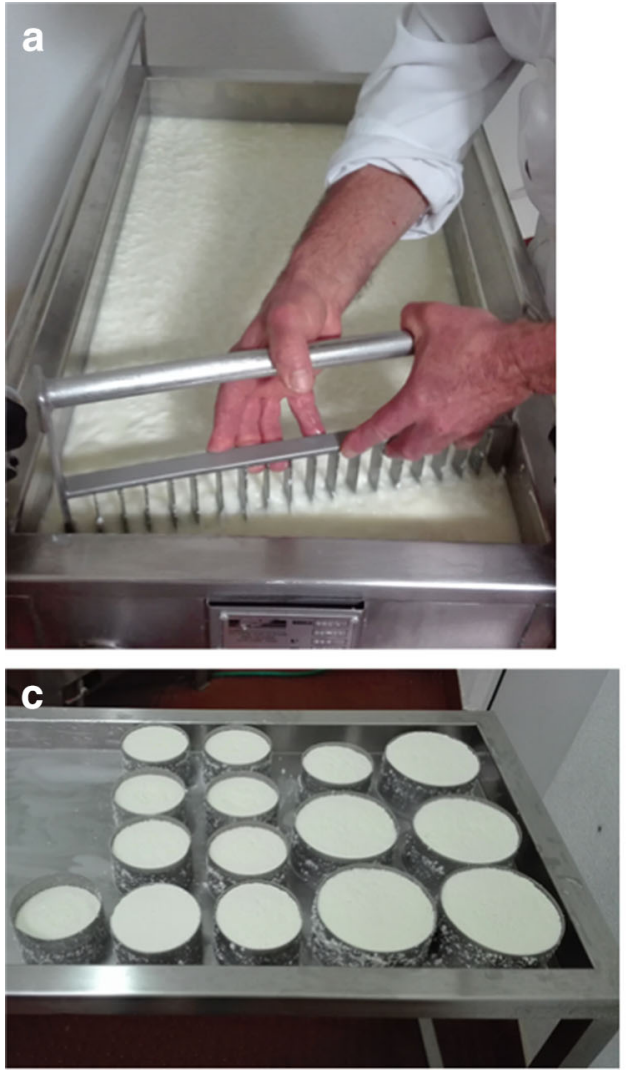
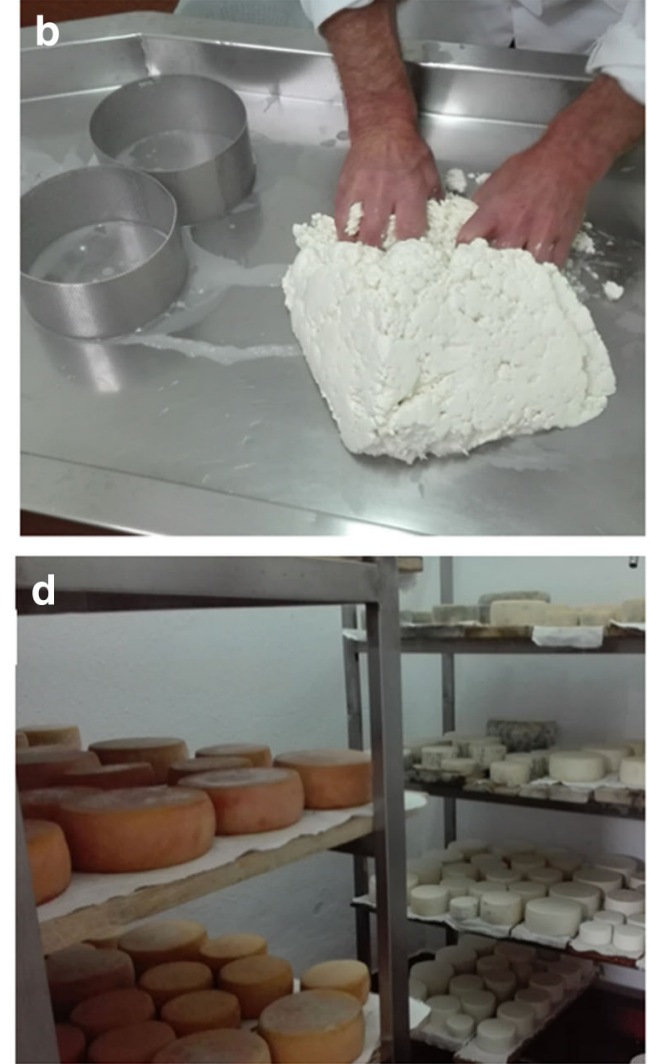

fat content. Another study done by Santos et al. (2008) further showed that there are no differences in meat quality of goats between male and female kids.

\section{Uses of the breed}

As previously stated, the Serrana breed is a dual-purpose breed and some of the ecotypes have a clear dairy aptitude. Nevertheless, goat milk is not usually consumed fresh in Portugal, except for on-farm consumption, and it is used in its entirety for cheese production (Carolino et al. 2017).

In the kid goat meat market, kids are usually sold and slaughtered at very young ages ( $2-5$ months old) and, in most cases, they are kept with the females in the herd during grazing until they are sold. In the absence of technological expertise in this area, the carcasses do not achieve the best conformation (Pereira, 2005). Following the trends of the lamb and kid market in Portugal, Serrana kids are sold mainly for the Easter and Christmas seasons (ANCRAS 2020).

The ecotypes Jarmelista and Ribatejano are exploited mainly for their milk aptitude and the Transmontano ecotype is exploited in the dual-function milk/meat (Barbosa et al. 2014). From this breed, two PDO and two PGI are produced. Transmontano kid PDO is produced in some parts of the Trásos-Montes region. The animals are mainly fed with spontaneous vegetation existing in the uncultured and fallow areas. The kids are fed with milk, being slaughtered at weaning, which occurs between 30 and 90 days of life. The carcass should weigh between 4 and $9 \mathrm{~kg}$. The milk from the goats is used to produce the Transmontano PDO goat cheese. The cheese is obtained from raw milk and is cured into an extra hard cheese with a slightly spicy taste. The cheese making is based on traditional methods. Firstly, the milk is heated to $35^{\circ} \mathrm{C}$, it is curdled, the curd is pressed manually to remove the whey and is placed in moulds, and salt is added and left to mature for at least 60 days, at a temperature between 5 and $18^{\circ} \mathrm{C}$ and a relative humidity of 70 to $85 \%$ (Direção-Geral de Agricultura e Desenvolvimento Rural 2020). In Fig. 5, some of the steps for traditional Serrana goat milk cheese making are shown.

The Barroso kid is produced in the Vila Real district (Trásos-Montes region) from Serrana and Bravia kids or from the crossing of the two breeds. The animals are produced in an extensive system, essentially with free grazing. They are occasionally housed during the winter. The feeding of the kids is essentially composed of goat milk and they are slaughtered at the age of 3 months, staying with the goats until slaughter age. The Minho Highlands kid has the same specifications but is produced in a different region and may be slaughtered between the second and fourth months of age. The Beira kid is produced in the centre of Portugal using both Serrana and 
Charnequeira breeds or their crosses. The production system is the same previously described but the kids are slaughtered at 40-45 days, under $7 \mathrm{~kg}$ (Direção-Geral de Agricultura e Desenvolvimento Rural 2020).

\section{Serrana goats and their importance in the establishment of tropical goat breeds}

Goat production in the Iberian Peninsula represents $25 \%$ of the total in the European Union, and there are 6 and 22 caprine breeds from Portugal and Spain, respectively, that are officially recognized to be poorly genetically differentiated since there are no geographical barriers and both countries had the custom of seasonal pastoralism and transhumance (Martínez et al. 2015). This production system made genetic exchanges among populations from distant places very easy (Manunza et al. 2016). Furthermore, and as a consequence of their size, adaptability and versatility, Iberian goats were transported to other continents, particularly the Americas during the colonial period (Ribeiro et al. 2011; Sevane et al. 2018). Until the end of the fifteenth century, domestic livestock (horses, goats, cattle, pigs) did not exist in the American continent (Gama et al. 2020), since their civilization just had domesticated a few animal species like South American camelids (Ginja et al. 2016).

The Creole goat breeds are an example of these species spread through the continent. Some studies assume that probably these breeds derive from goats that were brought by colonizers from the Iberian Peninsula and from the archipelagos of the Canaries and Cape Verde, where ships made stopovers to resupply (Ribeiro et al. 2011; Ginja et al. 2016; Sevane et al. 2018; Gama et al. 2020).

Sevane et al. (2018), using microsatellite markers, studied the genetic diversity of 71 breeds, including six Portuguese and 23 Spanish breeds. The main conclusion was that all Creole breeds originated from Iberian and African breeds and their genetic diversity derives from admixture between both lineages. Ginja et al. (2016) using a similar analysis studied the genetic diversity of 24 Creole goat populations from different countries. The Brazilian breeds showed a differentiation compared to other countries' breeds, which reinforces their common origin from goats introduced by the Portuguese in the colonial period. The Moxotó breed showed a pattern similar to that of the Serpentina breed with white or cream coat, black legs and a black stripe on the back. The breeds Graúna and Azul evidenced phenotypic patterns very similar to those of the Serrana breed. Ribeiro et al. (2011) also demonstrated that Brazilian breeds show signs of a common ancestry with Portuguese goats, especially Graúna and Canindé. These works clearly show the importance of Iberian breeds, and particularly the Serrana breed, in the establishment of the first tropical goat breeds in the Americas as well as the extraordinary adaptability of these animals to novel environments.

\section{Conclusions and future prospects}

The Serrana is an interesting goat breed to use in traditional production systems, leading to the production of highly valued and high-quality products. Being an autochthonous breed, it is well adapted to the local climate and production conditions. The breed is very rustic and is able to thrive in the harsh interior mountainous regions of North and Central Portugal. The extensive systems in which the breed is farmed lead to the possibility of producing high-quality products in a sustainable way. It would be important to work more in animal selection and benefit from the advantages of this breed with the aim of increased milk production and better carcass conformation. As this breed is the origin of different tropical breeds in Brazil, it would be interesting to conduct further genetic studies to ascertain the influence of the Serrana goat breed in the establishment of other local breeds in those countries.

\section{Compliance with ethical standards}

Conflict of interest The authors declare that they have no conflict of interest.

Ethics approval Not applicable.

Consent to participate Not applicable.

Consent for publication Not applicable.

Data availability Not applicable.

\section{References}

Almendra, L., 1996. A cabra Serrana transmontana - origem, caracterização da raça e sistemas de produção, Colêtanea S.P.O.C., 7, 31-55.

ANCRAS, 2020. Raça Serrana. http://www.ancras.pt/

Barbosa, J. C., Pereira, F, Neto, I. C., 2014. Contributos para a caracterização das explorações leiteiras de caprinos de raça Serrana em Trás-os-Montes. In: Instituto Politécnico de Bragança (ed), III Reunião Nacional de Caprinicultura, Bragança, 2014, 3640.

Bruno-de-Sousa, C., Martinez, A. M., Ginja, C., Santos-Silva, F., Carolino, M. I., Delgado, J. V., Gama, L. T., 2011. Genetic diversity and population structure in Portuguese goat breeds. Livestock Science, 135, 131-139.

Carolino, N., Bruno-de-Sousa, C., Carolino, I., Santos-Silva, F., Sousa, C., Vicente, A., Ginja, A., Gama, L., 2017. Biodiversidade caprina em Portugal . In: Bayona, J., Martínez, L., Bermejo, J., Galván, G. (eds), Biodiversidad caprina iberoamericana, Bogotá, 2016, 57-74.

Castro, M., 2016. Sistemas de produção animal em regiões de montanha em Portugal. In: J. C. Azevedo, V. Cadavez, M. Arrobas, J. M. Pires (eds), Sustentabilidade da Montanha Portuguesa realidades e desafios, Instituto Politécnico de Bragança, 2016, 127-147.

Correia, T. 2004. Estudo da variabilidade e relações genéticas em raças caprinas autóctones mediante microssatélites. [doctoral dissertation, University of Trás-os-Montes and Alto Douro]. Instituto Politécnico 
de Bragança digital library. https://bibliotecadigital.ipb.pt/bitstream/ 10198/2294/4/Tese\%20teresa.pdf

Correia, T., Ramiro, V., Azevedo, J., Mendonça, A., Gaivão, L., Mauricio, R., Cardoso, M., 2001. Determinación de la entrada en pubertad en cabras serrana nacidas en verano e invierno mediante análisis de progesterona e observación de celos. Revista de la Asociación Interprofesional para el Desarrollo Agraria, 22, 718-720.

Dantas, R., Espadinha, P. Pela defesa das raças autóctones portuguesas. In: SPREGA. 2020. http://www.sprega.com.pt/docs/PELA_ DEFESA racas.pdf. Accessed 25 Oct 2020.

DGAV (2018). Cabra Serrana Informação. Available online at: http:// srvbamid.dgv.min-agricultura.pt/portal/page/portal/DGV/ genericosgenerico $=27706122 \&$ cboui $=27706122$

Direção-Geral de Agricultura e Desenvolvimento Rural, 2020. Produtos tradicionais portugueses. https://tradicional.dgadr.gov.pt/pt/cat/ queijos-e-produtos-lacteos/32-queijo-de-cabra-transmontano

France Génétique Elevage. 2015. Races Caprines - Saanen. http://fr. france-genetique-elevage.org/Saanen.html.

Gama, L., Martínez, A., Ginja, C., Cañon, J., Martin-Burriel, I., Revidatt, M., Ribeiro, M., Jordana, J., Cortes, O., Sevane, N., Landi, V., Delgado, J., BIOBOVIS, BIOPIG, BIOHORSE, BIODONKEY, BIOGOAT, BIOVIS consortia, 2020. Genetic Diversity and Structure of Iberoamerican Livestock Breeds. In: Duarte, A., Costa, L. (eds), Advances in Animal Health, Medicine and Production, Switzerland, 2020, 52-68.

Ginja, C., Gama, L.,Martínez, A., Sevane, N., Martin-Burriel, I., Lanari, M., Revidatti, M., Aranguren-Méndez, J., Bedotti, D., Ribeiro, M., Sponenberg, P., Aguirre, E., Alvarez-Franco, L., Menezes, M., Chacón, E., Galarza, A., Gómez-Urviola, N., Martínez-López, O., Pimenta-Filho, E., Rocha, L., Stemmer, A., Landi, V., DelgadoBermejo, J., 2016. Genetic diversity and patterns of population structure in Creole goats from the Americas. Stichting International Foundation for Animal Genetics, 48, 315-329.

Hirst, K., 2019. The domestication of Goats. https://www.thoughtco.com/ the-domestication-history-of-goats-170661

Jiménez-Badillo, M. R., Rodrigues, S., Sañudo, C., Teixeira, A., 2009. Non-genetic factors affecting live weight and daily gain weight in Serrana Transmontano kids. Small Ruminant Research, 84, 125128 ,

Kukovics, S., 2018. Goat Science, (Intechopen. London).

Lopes, D. D., Fernández G. P., Poli, M., Moreira, G. R. P., Gonçalves, G. P., Freitas, G. R. O., 2016. Ancestry analysis of locally adapted Crespa goats from southernmost Brazil. Genetics and Molecular Research, 15(2), 1-16.

Mantas A., 2009. As raças autoctones. http://naturlink.pt/article.aspx? menuid $=66 \& \mathrm{cid}=3143 \& \mathrm{bl}=1 \&$ section $=1 \&$ viewall=true\#Go_1

Manunza, A., Noce, A., Serradilla, J., Goyache, F., Martínez, A., Capote, J., Delgado, J., Jordana, J., Muñoz, E., Molina, A., Landi, V., Pons, A., Balteanu, V., Traoré, A., Vidilla, M., Sánchez-Rodríguez, M., Sànchez, A., Cardoso, T., Amills, M., 2016. A genome-wide perspective about the diversity and demographic history of seven Spanish goat breeds. Genetics Selection Evolution, 48:52, 1-9

Margatho, G., Rodríguez-Estávez, V., Medeiros, L., Simões, J., 2018. Seasonal variation of Serrana goat milk contents in mountain grazing system for cheese manufacture. Revue de Médicine Véterinaire, 7-9, 166-172.

Margatho G., Rodríguez-Estévez, V., Quintas H., Simões J., 2019. The Efects of Reproductive Disorders, Parity, and Litter Size on Milk Yield of Serrana Goats, Animals, 9(11), 968-978.

Margatho G., Quintas, H., Rodríguez-Estévez V., Simões, J., 2020. Udder Morphometry and Its Relationship with Intramammary Infections and Somatic Cell Count in Serrana Goats, Animals, 10(9), 1534-1542.

Marques, P. X., Pereira, M., Marques, M. R., Santos, I. C., Belo, C. C., Renaville, R., Cravador, R., 2003. Small Ruminant Research, 50, 177-185.
Martínez, A., Gama, L., Delgado, J., Cañon J., Amills, M., Bruno-deSousa, C., Ginja, C., Zaragoza, P., Manunza, A., Landi, V., Sevane, N., 2015 The BioGoat Consortium. The Southwestern fringe of Europe as na importante reservoir of caprine biodiversity. Genetics Selection Evolution, 47, 1-13.

Mateus, O., Correia, T., Maurício, R., Pereira, F., Quintas, H., Carloto, A., Dendena, M., Valentim, R., Maneio reprodutivo em ovinos e caprinos. In: Redovicapra, 2015. http://www.ancras.pt/images/ redovicapra_pdf/Maneio_Reprodutivo.pdf. Accessed 30 Nov 2020.

Ministério das Obras Públicas, Comércio e Industrias, 1873. Recenseamento Geral dos Gados no Continente do Reino de Portugal 1870. In: Anidop 2015. https://anidop.iniav.pt/media/ contentbuilder/upload/2e011 efe31bd57952e1c2ed3030b694b 1873_Recenseamento_Geral_dos_Gados.pdf. Accessed 20 Oct 2020.

Pena J., 2018. As razões porque deve valorizar as raças autoctones portuguesas. https://agriculturaemar.com/as-razoes-porque-devevalorizar-as-racas-autoctones-portuguesas/

Pereira, F., 2005. A Raça Serrana. In: Teixeira, A. (ed), Novos Produtos cárneos, Bragança, 2005, 5-17.

Pereira F. (2015). Cabra Serrana, situação atual e perspetivas futuras. In: Instituto Politécnico de Bragança (ed). CAPRA 2015 - Reunião Nacional de Caprinicultura e Ovinicultura, Bragança, 2015, 54-58.

Pereira, F., Pereira, L., Van Asch, B., Bradley, D. G., Amorim, A., 2005. The mtDNA catalogue of all Portuguese autochthonous goat (Capra hircus) breeds: high diversity of female lineages at the western fringe of European distribution. Molecular Ecology, 14. 2313-2318.

Pires, A., Martins, D., Pardal, P., 2015. Caracterização das explorações da raça Serrana, ecótipo Ribatejano, na região Oeste. Revista da ESAS, 3(4), 36-60.

Quaresma, M., Rodrigues, I., Alves, S., Bessa, R., 2016. Meat lipid profile of suckling goat kids from certified and noncertifiedproduction systems. Small Ruminant Research, 134, 49-57.

Ribeiro, M., Bruno-de-Sousa, C., Martinez-Martinez, A., Ginja, C., Menezes, M., Pimenta-Filho, E., Delgado, J., Gama, L., 2011. Drift across the Atlantic: genetic differentiation and population structure in Brazilian and Portuguese native goat breeds. Journal of Animal Breeding and Genetics, 129, 79-87.

Santos, C., Silva, A., Silvestre, D., Silva, R., Azevedo, T., 2008. The use of multivariate analysis to characterize carcass and meat quality of goat kids protected by the PGI "Cabrito de Barroso". Livestock Science, 116, 70-81.

Sevane, N., Cortés, O., Gama, L., Martínez, A., Zaragoza, P., Amills, M., Bedotti, D. O., Bruno-de-Sousa, C., Cañon, J., Dunner, S., Ginja, C., Lanaria, M. R., Landi, V., Sponenberg, P., Delgado, J. V., The BioGoat Consortium, 2018. Dissection of ancestral genetic contributions to Creole goat populations. Animal, 12, 2017-2026.

Silva, J., Cruz, S., Barbosa, J., 2007 Estudo e desenvolvimento de estratégias para prevenção dos riscos associados ao clima quente, nas explorações de pequenos ruminantes, em Portugal. In: Pacheco, F., Morand-Fehr, P. (eds), $6^{\circ}$ Seminário Internacional da Rede FAO-CIHEAM sobre Ovinos e Caprinos Sub-Rede Sistemas de Produção, Ponte de Lima, 2007, 203-212.

Simões, J., Bauer, A., 2017. Reproductive and Milk Production Profiles in Serrana Goats. In: Simões, J., Gutiérrez, C., (eds), Sustainable Goat Production in Adverse Environments - Volume II. Cham: Springer International Publishing AG. p. 233-243.

Simões, J., Mascarenhas, R., 2007. Origin and characterisation of preovulatory follicles of hyperstimulated oestrus cycles in goats. Acta Veterinaria Hungarica, 55, 259-266.

Simões, J. Almeida, J. C., Valentim, R., Baril, G., Azevedo, J., Fontes, P., Mascarenhas, R., 2006. Follicular dynamics in Serrana goats. Animal Reproduction Science, 95, 16-26.

Simões, J., Baril, G., Almeida, J. C., Azevedo, J., Fontes, P., Mascarenhas, R., 2008. Time of ovulation in nulliparous and multiparous goats. Animal, 2:5, 761-768. 
Solaiman, S., 2010. Goat Science and Production, (Wiley-Blackwell, Iowa).

SPREGA. 2020. Caprinos - Raça Serrana http://www.sprega.com.pt/ conteudo.php?idesp $=$ caprinos\&idraca $=$ Serrana

Teixeira, A., Azevedo, J., Delfa, R., Morand-Fehrd, P., Costa, C., 1995. Growth and development of Serrana kids from Montesinho Natural Park (NE of Portugal), Small Ruminant Research, 16, 263-269.
Teixeira, A., Oliveira, A., Paulos, K., Leite, A., Marcia, A., Amorim, A., Pereira, E., Silva, S., Rodrigues, S., 2015. An approach to predict chemical composition of goat Longissimus thoracis et lumborum muscle by Near Infrared Reflectance spectroscopy. Small Ruminant Research, 126, 40-43.

Publisher's note Springer Nature remains neutral with regard to jurisdictional claims in published maps and institutional affiliations. 